\title{
Repair for a Broken Economy: Lessons for Circular Economy from an International Interview Study of Repairers
}

\author{
Johan Niskanen $^{1, *(\mathbb{D}}$, Duncan McLaren ${ }^{2} \mathbb{D}$ and Jonas Anshelm ${ }^{1}$ \\ 1 Department of Thematic Studies-Technology and Social Change, Linköping University, \\ 58183 Linköping, Sweden; jonas.anshelm@liu.se \\ 2 Lancaster Environment Centre, Lancaster University, Library Avenue, Lancaster LA1 4YQ, UK; \\ d.mclaren@lancaster.ac.uk \\ * Correspondence: johan.niskanen@liu.se
}

Citation: Niskanen, J.; McLaren, D.; Anshelm, J. Repair for a Broken Economy: Lessons for Circular Economy from an International Interview Study of Repairers. Sustainability 2021, 13, 2316. https://doi.org/10.3390/ su13042316

Academic Editor: Ana de Jesus

Received: 9 February 2021

Accepted: 17 February 2021

Published: 20 February 2021

Publisher's Note: MDPI stays neutral with regard to jurisdictional claims in published maps and institutional affiliations.

Copyright: (c) 2021 by the authors. Licensee MDPI, Basel, Switzerland. This article is an open access article distributed under the terms and conditions of the Creative Commons Attribution (CC BY) license (https:// creativecommons.org/licenses/by/ $4.0 /)$.

\begin{abstract}
The idea of replacing the broken linear economy with circular forms to help address the current sustainability crisis is gaining world-wide traction in policy, industry, and academia. This article presents results from an international interview study with 34 repair practitioners and experts in different fields. The article aims to improve understandings of the potential of repair so as to contribute to a more just, sustainable, and circular economy. Through a five-step qualitative method the results reveal and explore three tensions inherent in repair: first, repair activities constitute different forms of subjectivity; second, repair entails different and sometimes contested temporalities; and finally, even though repair is deeply political in practice, the politics of repair are not always explicit, and some repair activities are actively depoliticized. The opportunities and obstacles embodied in these tensions are generative in repair practices and debates, but poorly reflected in contemporary circular economy discourse. We conclude that a richer, more inclusive, and politicized understanding of repair can support environmental justice in the implementation of circular economy (CE) and provide greater opportunities for just and transformational sustainability strategies and policies.
\end{abstract}

Keywords: values of repair; circular economy; environmental justice; politicization

\section{Introduction}

The idea of introducing a more circular economy (CE) to meet the current sustainability crisis is gaining traction in policy, industry, and academia globally [1-3]. At its core, the idea of a CE is built on the reuse, recycling, and repair of materials and products through more circular models of production and consumption. Often CE is depicted as a butterfly diagram where the "wings" of the butterfly are made up of and represent biological circles (e.g., farming and regeneration of biological nutrients) on the one side and technical cycles (e.g., maintain, reuse, refurbish, and recycle) on the other side. The focus in this article is on repair-which is commonly understood in CE as an inner technological circle meaning that repair activities are understood to be integral to increased circularity of materials. Whilst CE is hailed as a transformational model in the way humans produce and consume material and immaterial goods [4,5], we argue that CE discourses reproduce a set of simplified cultural and sociological presumptions about repair that are not only likely to impede the uptake of more circular behaviors, but also to undermine the overall objectives of a CE in terms of supporting sustainability and justice.

Mainstream CE discourses present repair as a consumer activity, instrumentally supporting extended-notionally even indefinite-cycling of materials in the economy, delivered through new business models enabled by technocratic government interventions. The way that repair is understood in the CE discourse is reshaping the conditions, norms, and expectations under which citizens engage with or practice repair. In policy, repair is 
taken for granted as important for $\mathrm{CE}$ implementation and is considered as a job creator [6], but the topic is critically under-studied in academia $[7,8]$.

This study addresses this gap by studying tensions found in repair as it is practiced and contrasting the insights they offer with the ways repair is understood in the $\mathrm{CE}$ literature. By tensions we mean potential contradictions, understood as contested and debated spaces, not crude dualisms. Though interviews with a diverse international group of repairers (practitioners and experts), this article elaborates on three particular tensions in the social and cultural dimensions of repair activities, regarding the subjectivities they help constitute, the temporalities they reflect and the politics they embody and express.

We argue that exploring such tensions can help reveal both opportunities and obstacles with respect to social and environmental goals. Engaging with these can help guide CE actors to more just and inclusive practices. We have previously identified potential tensions from an analysis of $\mathrm{CE}$ and repair literature [8]. Here we elaborate, and explore the issues arising, based on a critical analysis of interviews with repair practitioners and experts against the backdrop of established understandings of repair in CE.

In the next section we summarize relevant theoretical understandings of repair in the $\mathrm{CE}$ literature and in the emerging field of sociology of repair. After that we present the research process and the five-step methodology applied. Then we present the results of the interview study focusing on three key tensions, followed by a discussion. The article concludes with implications for $\mathrm{CE}$ and environmental policy.

\section{Repair in Theory}

Repair is an endemic function of human society with direct and indirect effect on materials, social relations, and cultural norms and behaviors [9,10]. Repair in CE is however a relatively young field of research, with first publications around the year 2010 and with most works published from the year 2018 and onwards [8]. Even in this literature the role of repair is seldom a research topic in itself, but rather it is understood as one of several shallowly defined strategies for achieving more circularity, and its usefulness is understood to mainly lie in extending the lifetime of material objects and resources in the economy [11].

In the $\mathrm{CE}$ literature, the most visible actor groups are consumers and producers. Consumers are both understood as individuals owning or using things that need to be repaired (by others), and as an aggregated "market" for sustainable products and services. The consumer subject is especially prominent in business models such as product-servicesystems (PSS) which promise more "sustainable consumption" [12-15]. Repair focused CE literature emphasizes barriers to consumer repair such as information deficits, restrictive warranties, and poor product designs, e.g., [16-18] and sometimes highlights "empowerment" of consumers through a right-to-repair [19]. Repair centered CE literature also highlights economic and employment opportunities in diverse industry sectors [5,20-22], topics which are also emphasized in European Union policy [1]. Proposed policy interventions are typically technocratic, using market mechanisms to modify consumer behavior or support innovations in product design and business models. Repair in the CE is thus typically described in a limited and restricted way, generally supporting consumerist values, and sustaining the liberal capitalist economic model $[8,23]$.

In contrast the emerging field of sociology of repair presents a broader and deeper understanding of repair as a concept or activity evoking and expressing political and cultural values beyond the technocratic and consumerist descriptions which dominate $\mathrm{CE}$ literature. In this literature, repair is understood as a socially and politically contested activity $[24,25]$. This richer understanding of repair reflects "a widespread, creative, innovative and reconstituting capability and sensibility, rather than a narrowly-delineated process of restoring a given object to a certain specification in the context of a dyadic relationship between manufacturer and user" [26] (p. 133). This literature sees transformational potential in repair affecting subjectivities, temporalities, and politics.

In stark contrast to the "consumer subject" acting rationally upon an object, in the sociology of repair subjectivity is fundamentally relational: constituted and reconstituted 
in interactions with our fellow humans and various emanations of our material and living environments $[9,10,27]$. A relational understanding of repair includes but goes well beyond "attachment" to particular objects, and ideas of "emotionally durable design" [28] intended to trigger and sustain such attachment, as opposed to design that emphasizes novelty and fashion. It encompasses repair as a relationship with our communities, often expressed through collective forms of repair, and with the natural and material world [29].

The temporal dimension of repair not only embodies specific relationships with past and future, but also reflects the political implications of those relationships. Repair can act either to sustain or to transform individual and collective socio-material relations. Repair understood as the return of broken objects and systems to a prior state of function is a reminder of the durability of social and technical orders, but repair can also be a place and an opportunity for creativity and innovation [9]. The temporal standing of repair is thus ambiguous, it is simultaneously an issue of social order and social change. It can include forward-looking visions of change based on progressive norms [30,31]. Repair can also be nostalgic [32] and include reverence for a world that no longer exists, or a longing for a utopia that never was [33]. Artisanal work, craft skills, and taking pride in understanding how to use technologies can on the one hand be understood as a reaction to the alienation of work in offices and industries [8] - but on the other hand romantic and nostalgic understandings of repair can be a canvas for regressive and unjust social relations.

In its orientation to subjectivity and temporality, repair is thus inevitably political. However, it is not necessarily explicitly so. The politics of repair can be very personal, prefigurative, or more formal and explicit: for example, as a protest against a "throw-away" consumerist society. Repair may appear non-political (as, for example, a leisure activity), or it may be part of a process of depoliticization, as through, e.g., product-service-systems which offer sustainability as a consumption choice, building on the post-political neoliberal narrative of personal responsibility, while concealing the power relations involved in corporate control over products, or intrusion into privacy through "smart" appliances. Through legal campaigns, repair-and maker cafés, community tool libraries and online platforms, collective repair has been an activity for ecological action (in affluent societies) a politics built on an "ethos of sharing, commoning and mutuality" [30] (p. 637). While repair and maintenance can sustain the neoliberal status quo, some expressions of repair activism "play a significant role in resisting the commodification of the everyday" [30] (p. 637). Repair can thus be understood as (seemingly apolitical) rational individual consumer behavior, or alternatively as a form of explicit individual or collective political resistance to consumerism [8]. Repair also highlights unequal social relations as it is "not a voluntary choice for many, but rather a response to need (and to enforced state austerity policies)" [8] (p. 6).

Repair can thus take different social, temporal, and political expressions. This richness is however not visible in most CE discourse [8], which we argue is detrimental to a just and sustainable implementation of CE. Below we highlight the diversity of cultural norms and practices in repair and contrast them with the mainstream CE discourse. By first, in the next section the methodology for this study is presented.

\section{Materials and Methods}

This study forms part of a broader research project on repair in the circular economy: we have previously examined CE discourses [25], and reviewed repair and CE literature [8]. In this study we explore empirically some of the tensions previously identified in the literature. These tensions regard the different subjectivities involved in repair; how repair entails different and sometimes competing temporalities; and how repair can be political in practice, but certain activities of repair tend to hide politics. We understand these tensions to be contested spaces where repair can take different social, temporal, and political expressions. These tensions have been illuminated by interviews exploring how repairers understand the contexts and histories they act in and originate from, and variations in practices, norms, and beliefs. 
The research process involved five phases: (1) mapping of repair fields, inspired by Sennett [34] and McLaren [29]; (2) choice of a stratified sample of interviewees within identified repair fields across different disciplines, different geographies and cultures; (3) face-to-face and on-line interviews with selected repairers and experts; (4) coding and mapping of key themes regarding norms, practices, routines, conflicts and values in the interview material; and (5) a comparison of the interview material with representations of repair in CE literature identified in our previous research [8], and presentation of key insights. Through this we hope to explore the cultural questions associated with responsible and sustainable approaches to repair and to contribute to the discussion of repair in CE policies.

We mapped and selected a broad set of repair activities based on a selection of repair variations identified in previous studies on the cultural diversity of repair $[29,34]$. These categories are "reconstruction" (or restoration, meaning attempts to recreate a previous state, using the same materials for the same purposes); "remediation" (reinstating functioning, but potentially with different materials); "reconciliation" (establishing novel functioning relationships-between the same components or people); and "reconfiguration" (rearranging the components of something broken or disused to a new purpose or function). To enable a focus on issues relevant to $\mathrm{CE}$, we selected the fields of environmental restoration, material reconstruction, and community reconciliation for our study, rather than attempting a comprehensive survey of all fields of repair.

Based on the mapping we identified repair practitioners: professionals, volunteers, individuals, and experts for qualitative interviews within relevant repair fields. Eight face-to-face interviews and sixteen online video interviews were conducted with 34 individuals ( 15 women and 19 men) involved in repair activities in 13 countries in both the global North and South (see Appendix A for details). The interviews were conducted during 2020 and were each approximately one hour long. The interviewees included farmers, ecologists, hacker space enthusiasts, software engineers, textile workers, repair café convenors, scholars, etc. (see Appendix A for a list of interviewees). Here we do not specifically explore cultural variations rating to nationality, ethnicity, or genders-we focus on the variety of motives and meaning in repair activities rather than studying the diversity among practitioners.

The semi structured interview method was chosen to enable richer understanding of the norms and values of those who undertake repair. To minimize misunderstandings due to the mixed face-to-face and video approach and to allow interviewees to elaborate on their repair practices semi-structured interview guidelines were prepared in advance [35,36]. In this study we are interested in how repairers and experts understand repair. For us to gain insight to such meanings of repair our interview questions therefore concerned norms, routines, practices, behaviors, motivations, outcomes, expectations, frustrations and limits, controversies, history, fidelity and enhancement, and artefacts. In the analytical section of this paper, we interpret the interviews in order to understand the meaning of repair for repairers and experts. Interpretation is central for this qualitative research approach since qualitative research is concerned with meaning and meaning-making. Qualitative research is also inherently subjective since it includes the interpretation of such meanings. Of course, each interpretation process embodies many decision points which opens for different interpretations, but the objective of the approach is not to search for one true interpretationsince no such one exists-but to make sense of, and illuminate, a complex phenomenon through interpreting its meanings. To limit any biases the interviews have been conducted by two different interviewers and the material has been read by three analysts.

The rich empirical material provided by 34 interviews is here represented by illustrative quotations regarding the social, temporal, and political tensions explored in the interviews. Further analysis of other themes in the empirical material is planned. The following sections present and discuss the empirical material. 


\section{Results}

In this section we present the findings from our interviews, focusing on the three themes identified in the introduction: the ways in which repair constitutes the subjectivity of those involved, the relationships with past and future that repair practices embody, and the extent to which the politics of repair is explicit in practice.

\subsection{Subjectivity}

Here we highlight how repair reconfigures socio-material relations and subjectivity, as a relational process, often anti-consumerist, and often constructed collectively-yet with aspects which highlight individual self-actualization and ownership.

Our interviewees frequently described repair in terms of social and environmental relations, attachment, and intimacy. One even defined repair as "a form of being with regards to how we relate to other human[s] but also to our environment more broadly" (Interviewee 1). Others invoked relationality through ideas of care, one strikingly contrasting the need for a relational approach to repair and repairers with the contemporary digital economy: "I don't want repair to be Uberized [ ... ] it needs care" (I2).

Explicit attention to the outer environment is matched with insights as to personal development. For example, an interviewee involved in regenerative farming, seeking to repair natural systems explained how their involvement: "started [ ... ] in the frustration of realizing that the world ought to be improved [ ... ]. We wanted to live life and contribute to betterment. And it was the power of action that calmed our frustration" (I3). For this interviewee, regenerative farming exemplified a system of alternative sociomaterial relations re-orienting towards the world differently in relation to nature, in this case focusing on: "strengthening the processes that gives us clean water, healthy topsoil, and greater biodiversity and so on [ ... ] not to produce food but to strengthen these processes-so the food is a by-product" (I4).

Similarly, for several interviewees the benefit of repair was to be found as much in the sense of fulfilment and integrity it delivered, as in any material or economic benefit. As one interviewee put it: "there's a real delight in figuring stuff out [ . . ] [and] real delight in a feeling of having done the right thing" (I5). Such views come not only with a recognition of relationality, but also with a sense of agency, a self-actualization based in competence and skill, rather than in consuming. As one interviewee reported of repairers she had observed in an African city: "they very easily articulated a careful materially engaged culture [... ] [and would] contrast it with my cultural background that they felt was much more consumerist and much more wasteful" (I2). While one interviewee claimed that in Europe, repair is more about "emancipation and then removing oneself from consumerism, market relations and stuff like that" (I6).

However, in many settings the material benefits of repair remain critical. In another African city, our interviewee described how repair is an essential process of mending or stitching together everyday lives just to keep them going: "without the daily repair, without the daily mending, it's impossible to somehow continue to live and sustain that life" (I1). This is strikingly similar to the simple "perseverance" described in repair as maintenance of daily life in an industrial sacrifice zone in South America by a different interviewee: "repairing your land, taking care of your trees [ . . ] taking care of your children [ ... ] your loved ones that are ill due to contamination [ ... ] that whole network of practices that $[. .$.$] take care of that web of beings, human or not" (I7).$

Interviewees in the global North also stressed the community aspects of repair. Here, repair is more often a leisure or a pastime activity that people engage in for the value of social interaction. One repair café convenor noted how some café users would "find things to bring" so as to experience the positive environment and community of the café (I8). Our regenerative farmer similarly emphasized the community building value of their activities, and members of a sewing circle in the UK all concurred that the "social part is the most important" (I9), while also emphasizing their efforts to better support those in need in the local community. In a US based programme where second-hand solar 
energy equipment is repaired and put back in service to help low-income households, our interviewee stressed the social benefits to the community: "[the beneficiaries get] lights so the kids can study at night, [ . . ] [and] when we help out our local agricultural producers [ ... ] we are contributing to food security within the County" (I10).

Sometimes personal achievement and community building can be two sides of the same coin. A volunteer at a bike-repair workshop reported: "they planned for 'idiots' like me to come who can spend weeks making one bike shiny. However, most who come are refugees in need of a functional bike and they [ . . ] are very grateful for what used to be a piece of junk. This makes me emotionally attached to this" (I11). Here ethics of excellence and service to others in repair run together, both reflecting a deep relationality - to the process, and to the community, respectively. Another expert reported how repairers talk of the things they maintain in relational terms which attribute forms of agency to the objects of repair, not just the repairer: "as if they have personalities and require certain forms of worship or something to keep going" (I12).

Somewhat paradoxically, then, repair often implies strong relations between humans and things, with firm and enduring attachments. Indeed, as expressed by some activists, the "right-to-repair" is a consequence of ownership - a consumer right which should not be restricted by the product manufacturer (I13). Similarly, the provision of repair services, warranties, and other measures to enable repair can also help construct consumer subjectivities, especially around possessions that are important to our personal identities.

Repair practices reveal important tensions regarding subjectivity-not only between consumer and citizen, but between the individual and the collective. In contrast with the narrower individualistic consumer subjectivity implied in much CE discourse, the rich relational subjectivities constituted in repair raise important questions. How far should CE rely on-and risk reinforcing-consumerism, as opposed to empowering individual and collective agency? Can repair become a tool for human wellbeing and self-actualization, with reconfigured healthy relations with people and planet?

\subsection{Temporality}

We turn to the second space of tension-around temporal orientation. Here we see that repair practices again embrace rich and potentially generative tensions and contradictions. Repairers often look simultaneously backwards and forwards, seeking transformational outcomes from actions that maintain or restore past values. However, they typically exhibit awareness of the risks of romanticizing or nostalgizing an unequal past, or of disruption of the present for purely economic motives.

To repairers, repair is almost never self-evidently concerned purely with restoring the former functionality of objects. Repair can be about maintaining material arrangements, but more often reflects values—sometimes recovering past values, and in other cases using repair to express forward-looking, transformational values (sometimes values of sustainability are involved, typically then contrasted with their absence in contemporary society).

Many interviewees highlighted the recovery of values such as "make-do and mend", and the Japanese "mottainai" (regret over waste) as a foundation for sustainability. Several interviewees reflected on their upbringing as a source of such values, even though they themselves do not face the material constraints of previous generations. Most however, were also alert to a risk of romanticizing the past:

"We refer back to a time when repairing stuff was easier, but it was also easier because computers were far more expensive, far more sustainable, but also far more an elite thing. [... ] There is this nostalgia for the idea that people used to be able to repair their own things, but I am not sure that this was ever the case. [ . . ] Yeah, I think that is one of the most nostalgic tropes like, 'We used to be able to repair the car, and now we cannot do that anymore'" (I14).

There are wider risks with a nostalgia for lost worlds, "where some people had more social power than they seem set up to have in the 21st century" (I15). Romanticizing a 
nostalgic past that never was can be a fertile ground for regressive politics as visible in, for example, the current rise of "post-modern conservatism" [37].

In contrast, the creativity embodied in repair can generate a forward-looking transformation. In Kampala for example, repairers are very pragmatic: "the reverse of nostalgic ... really curious and creative people who are just expanding their knowledge continuously" (I2). This "creativity of repair" is future oriented and generates transformation. For younger generations, a good decision as to whether to repair or not should reflect future values, especially regarding sustainability: "If there's a value in that in terms of future generations being able to live a good quality of life that we want to live for ourselves, or for thinking about the consequences that would happen for all community members" (I15). Moreover, social repair, as one sewing circle member described with respect to her home country of Colombia, involves a future orientation, not just attention to the past: "a lot of different groups [are] working on repairing and embracing. [...] They can get together because they care, because it's important. Not only what happened before, but they're building for the future" (I9).

While often looking to the future, repairers are clear that novelty and disruption are not desirable for their own sake, or for purely economic motives. We heard examples such as the dangers of "fast fashion" co-opting the semiotics of repair, with "pre-patched jeans" (I9) and the increased precarity for repair workers in gig-work models inspired by ideas of circular product sharing (I2).

For our interviewees, therefore, repair is not self-evidently good or bad but must be related to broader "ends" viewed at a system scale. The question is not just should a particular thing be repaired but should the system within which it is embedded be maintained: "we need to know to what extent to repair, because it's so enamored in this idea of return, to what extent that it helps us to make [the] bigger transformations that we need to make" (I2). Moments of breakdown therefore offer important opportunities for reflection and re-evaluation.

In the CE literature, temporality is often taken for granted so that repair means a return to a previous material state. In contrast, in this study, working with temporal tension makes repairers alert to a wider range of questions. A nostalgic evocation of past values more often accompanies choice to repair seen in the global North than in circumstances of necessity - the "perseverance" or "stitching" required in daily life in poor communities in the global South. However, evocation of past values seems important to mobilizing repair and rejecting consumerism, at least for elders, while a more contemporary sustainability ethic is reportedly more influential for youth (I19). The pendulum movement between past, present, and future evokes the questions: whether to repair, and how repair practices might embody possibilities for transformation or reconfiguration? What is it that needs sustaining, and what is it that should be transformed in the act of repair?

\subsection{Politicization}

Questions of subjectivity and temporality are inevitably political, but not necessarily explicitly so. Here we highlight the range of political expression in repair, and the ways in which repair is actively politicized or depoliticized. Politically, repair can be an action against environmental degradation and natural resource overuse, or against increased commodification of previously private or public areas of our lives. Some interviewees linked these, while others contrasted them:

"More and more people are probably using repair as a political act. I do it myself indirectly for a political reason: mainly for environmental policy reasons. But there are those who do so also for left-wing political reasons as a critique of capitalist society".

From repair café convenors, we heard a similar tension, between those who saw repair as a political movement, and those who rather emphasized it as a practical response to environmental problems. Amongst our interviewees, campaigns for "rights-to-repair" 
are more widely understood as explicitly political, and in practice repair is often seen as a deliberate act of anti-consumption. This understanding is in direct opposition to the dominant framing of repair in $\mathrm{CE}$, which is concerned with facilitating green consumption (for more of this discussion see [12-18]). Framing repair in consumption terms as a service system can thereby be depoliticizing as this strips repair of its critical potential and it strips repairers of their political agency. The effect is that CE perpetuates existing and emerging commodification and marketization processes of repair, making it a tool for sustaining the status quo of an extractive economy rather than changing it. One interviewee highlighted "huge efforts [ ... ] by the industry to rebrand themselves and to implement, recycling initiatives and circular economies, etcetera" which are understood by communities on the ground in South America as "efforts to just keep capitalism going [ . . . ] an oxymoron" (I7).

Another interviewee emphasized the political economy of a recycling focus in $\mathrm{CE}$, rather than repair:

"Repair is too complicated [ ... ] it's easier just to melt and dissolve down and reclaim these materials at high energy cost, automated, as part of the fourth industrial revolution, and get the materials back to the manufacturing plants. I could see that being discussed at seminars in Davos. Whereas this much more situated, repairing, labor intensive [approach]—because of the nonconformity and non-standardization of all these components, activities - [ . . . ] doesn't fit a political economy we have at the moment, but probably is more sustainable".

In this sense repair is "not political enough" since the political economy of modern society makes repair "unthinkable" in many circumstances (I2). There is a political economy of why things are not made for disassembly and attempts at repair can reveal this in illuminating ways: "you go from a very specific act [ ... ] and suddenly the whole kind of political economy and cultures of 21st century consumption, kind of loom up out of the glue" (I17).

Some repairers respond with frustration to what they perceive as a lack of responsibilityand a tendency to co-opt sustainability issues for marketing benefit-built-in to this extractive politico-economic system:

"The important question is how [regenerative practices] can be scaled up without being kidnapped by industry and institutions. [ . . . ] You must be very careful and be aware that this can be kidnapped and distorted if we don't take our responsibility and think for ourselves. [ ... ] A paradigm shift is very much associated with individuals' decisions to take greater responsibility for their own lives".

For other interviewees, the critical political issue was that particular groups and community's dependence on every-day repair and maintenance was unrecognized. In virtually every case we heard about where repair was driven by necessity, it was typically undervalued, invisible, even stigmatized. Amongst waste-pickers in Africa, and craft-repairers in the UK, we were told, recognition visibility and convening of group identity had to precede collective action to defend livelihoods based on repair, and we repeatedly heard how gender expectations persist in undervalued repair activities.

In the absence of collective political solutions, repair can become an individual or community scale prefigurative response to a system that is understood to be broken. Selfsufficiency is a core value for many repairers, especially men. This means to provide for family and the local community and at the same time repair and maintain socio-material relations. Repair becomes an issue of agency and of control. In this respect, CE business solutions such as product-service-systems [12-18] are tools of centralized control over repair that run counter to community-based repair and "[tighten] the screws on the consumer [ ... ] Unless they're well designed, they can become a monopolistic stranglehold where consumers have even less rights" (I2). 
To summarize, in several ways repair is seen as simultaneously not political and deeply political: on the one hand, "repair doesn't seem political, because it's re-establishing something" (I6), on the other hand repair becomes intensely political where it questions its purpose or ends or-its role in a larger system-and repair can then become a "strategy for changing the world" (I6). As part of a CE, repair is presented as a win-win approach for business, workers, and the environment within a sustained capitalist economy, brushing away all sorts of political questions. However, our interviews revealed tensions between formal and prefigurative; and personal and collective expressions of politics, especially in a context of depoliticization of repair activities by corporate practices. These tensions raise important questions: Can greater visibility of repair help reveal the politics and inequalities involved? Can the practical politics of repair be harnessed to reconfigure the depoliticized arena of CE?

\section{Discussion}

We have seen that in practice, repair and repairers work within multiple tensions regarding subjectivity, temporality, and politicization. By contrast, mainstream CE discourse simplifies all three dimensions. It presumes market relations for repair, largely abstracted from both history and politics.

Firstly, CE proponents presume the dominance of markets, and actively seek to extend them [38] reframing repair activities, and even products as marketable services [12-18]. Repair constitutes part of a strategy to retain materials in the economy for longer [39-41], notably through new business models, such as product-service-systems. Repair also constitutes a labor category and a way to generate additional "green" jobs [1,5,20-22]. Repair is consistently presented as a market activity undertaken by independent rational economic agents acting upon inanimate objects, rather than a multi-dimensional relational process co-constituting the subjectivity of those actors.

This marketization of repair is perhaps best understood as an example of increased supply of services, such as product-service-systems (PSS) [12-18]. These business models construct specific consumer and producer subjects and validate individual ownership and consumption. Repair understood as a professionalized service means that citizens are either consumers of goods with repair rights, or they are leasers of goods owned and repaired by other agents. In PSS, rather than building relational engagement and skilled agency, repair is achieved by consumers relinquishing possession of goods to corporations, taking instead the role of service users or leasers.

In our material, however, we see that repair reconfigures individual and collective relations. In some settings it is a tool for people to establish their identities and express their environmental values, and in others it is a vital necessity of day-to day survival. In some places it is an individual skill supporting needs of self-actualization; and in others it is a community building practice. However, in none of these emanations is it dependent on markets and wage-relations.

Secondly, CE discourses largely abstract from temporality. Not only with an ideal of an indefinite cycle of materials, but also in the presumption of contemporary market capitalism and its incumbent social and economic relations [24,30]. CE discourses promise environmental transformation abstracted from social struggle and the history of extractivism. Repair is presented simply as an instrument for material restoration. However, in our material tensions between change and stability are ever-present in repair activities. On the one hand there are forward-looking visions advocating a more agential citizen, who take more responsibility for herself, her things, and her environment. Here values such as equality and increased practical and technological knowledge are central, echoing the post-industrial and emancipated mankind envisioned by Illich [42]. While such visions are progressive, repair also has a retrotopian side-drawing on a longing for a utopian past [33]. A retrotopian notion of repair is visible, e.g., in the trope of forgone skilled (often) male laborers (often fathers) who could repair anything, an important figure in some repair narratives. This underscores a darker longing for a simpler and idealized past with 
resemblance to tropes found in new conservative movements [37]. Nonetheless, repairers are typically alert to such risks, and to the potential social relations repair (re)configures.

Thirdly, CE discourses are generally depoliticizing. In part this is a direct product of their presumption of market relations, and their abstraction from history. However, it is also a product of power of corporate actors to shape discourses and shape $\mathrm{CE}$ as a question of business models and design approaches [8,25]. As a result, the representation of repair in the mainstream CE discourse completely lacks a political framework [24].

However, in all the emanations reported here, repair is political. When repair is understood as "politics in practice" - e.g., as a statement against a wear-and-tear society [31], it is not only an example of sustainability in practice, but also an important political transition agent. Repair understood as a community activity tends to come with collective social values of community building. Moreover, while repair understood as an individualized activity comes with values emphasizing individual consumer rights, it also illuminates the relations of care that comes with ownership. Perhaps most importantly, repairers highlight the political opportunities that come in moments of breakdown-particularly to decide what should be restored, and what should be transformed. As one interviewee stated: when repairing, the political economy and cultures of 21st century consumption "loom up out of the glue" (I17). The significance of such visible moments as opportunities to reconsider systems is perhaps best illustrated by some of the examples we were given of things that should not be repaired: redundant polluting factories (I12), or even more strikingly, the weapons, or equipment deliberately broken by peace or environmental activists such as Ploughshares or Earth First! (I17). Highlighting breakdown and repair-even when normalized — can also expose the social and political relations that underpin the existing situation, such as the persistent international relations and inequality exposed in some interviews: "when things break down, you see it, so it makes repair more visible but in the other way around where breakdown is the norm, repair is really mundane because everything around you is breaking down and we are repairing all the time" (I1).

$\mathrm{CE}$ discourse thus fails to engage with social implications and depoliticizes sustainability challenges $[8,25]$. The failing is deep-rooted: in CE discourse it is presumed that the world can be described in technological circles on the one hand (e.g., reuse, recycling, and repair of materials) and in biological circles on the other hand (as in the butterfly diagram popularized by the Ellen McArthur Foundation [39]). In this simplified world view, materials are never part of contested social, historical, or political relations. It is a model that assumes that materials can easily be governed to reach environmental benefits. This resembles the notion that $\mathrm{CO} 2$ emissions could be successfully governed with emissions markets. Like proponents of taxing away global warming, CE advocates are very reliant on abstract future developments: future circular technologies and business models are expected to be more efficient and this will solve all environmental problems related to resource use. This core idea turns every relation into a technological relation, and it hides the economic, cultural, and political aspects of $\mathrm{CE}$.

\section{Conclusions}

Repair can be seen as an instrumental tool that closes loops and facilitates continued consumption and market capitalism. However, it could also be a mechanism that responds to breakdown by enabling re-evaluation of how we interact in, and with this world. To repair the broken economy is a social and political task, to ensure that resources are not only cared for but also fairly distributed. To act as a responsible collective we must confront the status quo and discuss the contradictions inherent in CE policy and discourse. Understanding repair as a diverse and contested space rather than an exception from such contestation encourages such responsible deliberation. Critical social science can also better inform such debate by scrutinizing empirical cases of CE.

Seeing CE through the lens of repair can highlight tensions within CE and help make environmental policy more transformational, rather than patching up and sustaining socially unsustainable practices [43]. From a political perspective it could be argued that CE 
concerns the distribution of material benefits that comes with a turn to a greener industrial society, developed under the European Green Deal [44] and EU's COVID-19 recovery plan: "Europe's moment: Repair and Prepare for the Next Generation" [45]. A more inclusive understanding of repair has a role to play to ensure equality in the implementation of such policy packages. In this context, CE measures could be critical. CE interventions which lack attention to the subjectivity, temporality and politics of repair practices cannot be expected to deliver sustainability and justice, nor will CE policies increase rates of repair and broaden participation in repair activities if they rely simply on market mechanisms, overlooking the rich complexity of motivations for repair revealed in consideration of the issues of relationality and subjectivity.

A more inclusive understanding of the social and cultural roles that repair activities play means greater opportunity to present transformational CE policies. This study of repair activities suggests that policy should focus on the richness of social, cultural, and political aspects of repair beyond the citizens-as-consumers model that currently rules the discourse. In the CE literature, temporality is often not visible-or rather it is taken for granted that repair is a return to a previous material state. However, repair in practice can be forwardlooking and an action for political change: repairs taking place in communities broken by austerity or Covid-19 are political as well as transformational actions. Moreover, if we take breakdown as an opportunity to re-evaluate whole systems-and the social and economic relations they embody, then the repairs needed for our broken economy clearly go well beyond the introduction of circular loops but require attention also to repair the damage of economic inequality and other forms of discrimination and histories of environmental and colonial exploitation. It would be fair to suggest that CE measures cannot be asked to resolve all these problems too, but with their simplified and depoliticized presumptions about people, history and politics, mainstream CE discourses risk exacerbating such harms.

So, we return to the butterfly diagram. The technological and the biological wings of the CE butterfly diagram need to be supplemented with social and cultural understandings so that CE is thoroughly understood as more than an instrument for the prolongation of materials in the market. This article shows a diversity of values and behaviors in repair-but all repair activities have the commonality that they are deeply embedded in society. This socio-material embedding of repair needs to be better mirrored in CE policy. An increase of repair in existing sectors might slow down the extraction of primary resources-but this ought not be done at the price of ignoring the diversity of existing repair activities. If $\mathrm{CE}$ is to meet the global crises that its proponents claim it must address, CE policy should consider this diversity and learn from it. For environmental and CE policy this means to design instruments facilitating repair as well as at the same time go beyond taxation as a "solution" and facilitate local repair activities of various kinds.

Author Contributions: J.N. and D.M.: conceptualization, methodology, investigation, and writing. J.A.: project administration, funding acquisition, and review. All authors have read and agreed to the published version of the manuscript.

Funding: This research was funded by Svenska Forskningsrådet Formas, grant FR-2017/0007 and with support from the Mistra-Formas Environmental Humanities Collaboratory "The SeedBox".

Informed Consent Statement: Informed consent was obtained from all subjects involved in the study.

Acknowledgments: The authors wish to express our gratitude to all the interviewees for contributing with their time and knowledge. Thanks are also due to participants at the STRIPE seminar at TEMA, Linköping University in December 2020, for their constructive feedback on a draft of this paper. We also wish to thank three anonymous reviewers for their swift and helpful feedback.

Conflicts of Interest: The authors declare no conflict of interest. 
Appendix A Interviewees

\begin{tabular}{|c|c|c|c|c|c|}
\hline Interviewee (I) & Repair Field(s) & Activity & Actor Role & Gender & Geographical Focus \\
\hline 1 & $\begin{array}{c}\text { Material } \\
\text { reconstruction }\end{array}$ & Waste picking & Expert/scholar & Female & Ghana \\
\hline 2 & $\begin{array}{c}\text { Material } \\
\text { reconstruction }\end{array}$ & Repair services & Expert/Scholar & Female & Uganda, UK \\
\hline 3 & $\begin{array}{c}\text { Environmental } \\
\text { restoration }\end{array}$ & Farming & Practitioner & Female & Sweden \\
\hline 4 & $\begin{array}{l}\text { Environmental } \\
\text { restoration }\end{array}$ & Farming & Practitioner & Female & Finland \\
\hline 5 & $\begin{array}{c}\text { Material } \\
\text { reconstruction \& } \\
\text { community } \\
\text { reconciliation }\end{array}$ & Repair skills & Expert/Practitioner & Female & US \\
\hline 6 & $\begin{array}{c}\text { Material } \\
\text { reconstruction }\end{array}$ & Repair practices & Expert/Scholar & Male & UK \\
\hline 7 & $\begin{array}{l}\text { Community } \\
\text { reconciliation \& } \\
\text { environmental } \\
\text { restoration }\end{array}$ & Maintenance & Expert/Scholar & Male & Chile \\
\hline 8 & $\begin{array}{c}\text { Material } \\
\text { reconstruction }\end{array}$ & Repair cafes & Expert & Male & UK \\
\hline 9 & $\begin{array}{l}\text { Material } \\
\text { reconstruction \& } \\
\text { community } \\
\text { reconciliation }\end{array}$ & Textiles & Practitioner & Female & UK, Colombia \\
\hline 10 & $\begin{array}{l}\text { Community } \\
\text { reconciliation }\end{array}$ & $\begin{array}{l}\text { Renewable } \\
\text { energy }\end{array}$ & Practitioner & Male & US \\
\hline 11 & $\begin{array}{c}\text { Material } \\
\text { reconstruction }\end{array}$ & Bicycle repair & Practitioner & Male & Germany \\
\hline 12 & $\begin{array}{c}\text { Material } \\
\text { reconstruction }\end{array}$ & $\begin{array}{l}\text { Repair and } \\
\text { maintenance } \\
\text { practices }\end{array}$ & Expert/Scholar & Male & US \\
\hline 13 & $\begin{array}{c}\text { Material } \\
\text { reconstruction }\end{array}$ & $\begin{array}{l}\text { Maintenance } \\
\text { services }\end{array}$ & Expert/Scholar & Male & EU \\
\hline 14 & $\begin{array}{c}\text { Material } \\
\text { reconstruction }\end{array}$ & $\begin{array}{l}\text { Electronics- } \\
\text { hackerspace }\end{array}$ & Practitioner & Male & Germany \\
\hline 15 & $\begin{array}{l}\text { Material } \\
\text { reconstruction \& } \\
\text { community } \\
\text { reconciliation }\end{array}$ & Repair practices & Expert/Scholar & Male & US \\
\hline 16 & $\begin{array}{c}\text { Material } \\
\text { reconstruction }\end{array}$ & Textiles & Practitioner & Male & Sweden \\
\hline 17 & $\begin{array}{c}\text { Material } \\
\text { reconstruction }\end{array}$ & $\begin{array}{c}\text { Hackerspaces \& } \\
\text { makerspaces }\end{array}$ & Expert/Scholar & Male & UK \\
\hline 18 & $\begin{array}{l}\text { Environmental } \\
\text { restoration }\end{array}$ & Farming & Practitioner & Male & Sweden \\
\hline
\end{tabular}




\begin{tabular}{|c|c|c|c|c|c|}
\hline Interviewee (I) & Repair Field(s) & Activity & Actor Role & Gender & Geographical Focus \\
\hline 19 & $\begin{array}{c}\text { Material } \\
\text { reconstruction }\end{array}$ & Repair practices & Expert/Scholar & Male & UK/Vietnam/Japan \\
\hline 20 & $\begin{array}{c}\text { Material } \\
\text { reconstruction }\end{array}$ & $\begin{array}{l}\text { Sustainable } \\
\text { business }\end{array}$ & Practitioner & Male & India \\
\hline 21 & $\begin{array}{c}\text { Material } \\
\text { reconstruction }\end{array}$ & $\begin{array}{l}\text { Sustainable } \\
\text { consumption }\end{array}$ & Expert/Scholar & Male & UK/EU \\
\hline 22 & $\begin{array}{c}\text { Material } \\
\text { reconstruction }\end{array}$ & Textiles & Practitioner & Female & UK \\
\hline 23 & $\begin{array}{c}\text { Material } \\
\text { reconstruction }\end{array}$ & Textiles & Practitioner & Female & UK/Peru \\
\hline 24 & $\begin{array}{c}\text { Material } \\
\text { reconstruction }\end{array}$ & Textiles & Practitioner & Female & UK \\
\hline 25 & $\begin{array}{c}\text { Material } \\
\text { reconstruction }\end{array}$ & Software & Practitioner & Female & Canada \\
\hline 26 & $\begin{array}{c}\text { Material } \\
\text { reconstruction }\end{array}$ & $\begin{array}{l}\text { Electronics- } \\
\text { hackerspace }\end{array}$ & Practitioner & Female & Germany \\
\hline 27 & $\begin{array}{l}\text { Community } \\
\text { reconciliation }\end{array}$ & Farming & Practitioner & Female & US \\
\hline 28 & $\begin{array}{c}\text { Material } \\
\text { reconstruction }\end{array}$ & Software & Practitioner & Male & US \\
\hline 29 & $\begin{array}{c}\text { Material } \\
\text { reconstruction }\end{array}$ & $\begin{array}{c}\text { Sustainable } \\
\text { business }\end{array}$ & Expert/Scholar & Male & India \\
\hline 30 & $\begin{array}{c}\text { Material } \\
\text { reconstruction }\end{array}$ & $\begin{array}{l}\text { Sustainable } \\
\text { business }\end{array}$ & Expert/Scholar & Female & US \\
\hline 31 & $\begin{array}{l}\text { Environmental } \\
\text { restoration }\end{array}$ & Wildlife Heritage & Practitioner & Female & Sweden \\
\hline 32 & $\begin{array}{l}\text { Environmental } \\
\text { restoration }\end{array}$ & Ecology & Practitioner & Male & Sweden \\
\hline 33 & $\begin{array}{l}\text { Environmental } \\
\text { restoration }\end{array}$ & Ecology & Practitioner & Female & Sweden \\
\hline 34 & $\begin{array}{c}\text { Material } \\
\text { reconstruction }\end{array}$ & $\begin{array}{l}\text { Building } \\
\text { restoration }\end{array}$ & Practitioner & Male & Sweden \\
\hline
\end{tabular}

\section{References}

1. European Commission. A New Circular Economy Action Plan for a Cleaner and More Competitive Europe; Report No. COM(2020)98 Final; European Commission: Brussels, Belgium, 2020.

2. SITRA. Circular Economy Business Models for the Manufacturing Industry; SITRA: Helsinki, Finland, 2018.

3. Merli, R.; Preziosi, M.; Acampora, A. How do scholars approach the circular economy? A systematic literature review. J. Clean. Prod. 2018, 178, 703-722. [CrossRef]

4. Stockholm Environmental Institute. Transformational Change through a Circular Economy; Stockholm Environmental Institute: Bangkok, Thailand, 2019.

5. Webster, K. The Circular Economy: A Wealth of Flows; Ellen MacArthur Foundation Publishing: Cowes, UK, 2017.

6. European Commission. Impacts of Circular Economy Policies on the Labour Market; European Commission: Brussels, Belgium, 2018.

7. Schöggl, J.P.; Stumpf, L.; Baumgartner, R.J. The narrative of sustainability and circular economy-A longitudinal review of two decades of research. Resour. Conserv. Recycl. 2020, 163, 105073. [CrossRef]

8. McLaren, D.; Niskanen, J.; Anshelm, J. Reconfiguring repair: Contested politics and values of repair challenge instrumental discourses found in circular economies literature. Resour. Conserv. Recycl. 2020, 8, 100046. [CrossRef]

9. Jackson, S.J. Repair as Transition: Time, Materiality and Hope. In Repair Work Ethnographies; Strebel, I., Bovet, A., Sormani, P., Eds.; Palgrave McMillan: London, UK, 2019; pp. 337-348. 
10. Henke, C.R. Negotiating Repair: The infrastructural contexts of practice and power. In Repair Work Ethnographies; Strebel, I., Bovet, A., Sormani, P., Eds.; Palgrave McMillan: London, UK, 2019; pp. 255-282.

11. Kalmykova, Y.; Sadagopan, M.; Rosado, L. Circular economy-From review of theories and practices to development of implementation tools. Resour. Conserv. Recycl. 2018, 135, 190-201. [CrossRef]

12. Stål, H.I.; Corvellec, H. A decoupling perspective on circular business model implementation: Illustrations from Swedish apparel. J. Clean. Prod. 2018, 171, 630-643. [CrossRef]

13. Cherry, C.E.; Pidgeon, N.F. Why is ownership an issue? Exploring factors that determine public acceptance of product-service systems. Sustainability 2018, 10, 2289. [CrossRef]

14. Stål, H.I.; Jansson, J. Sustainable consumption and value propositions: Exploring product-service system practices among Swedish fashion firms. Sustain. Dev. 2017, 25, 546-558. [CrossRef]

15. Yang, M.; Smart, P.; Kumar, M.; Jolly, M.; Evans, S. Product-service systems business models for circular supply chains. Prod. Plan. Control 2018, 29, 498-508. [CrossRef]

16. Mugge, R. A consumer's perspective on the circular economy. In Routledge Handbook of Sustainable Product Design; Routledge: London, UK, 2017; pp. 396-412.

17. Flipsen, B.; Bakker, C.; van Bohemen, G. Developing a reparability indicator for electronic products. In Proceedings of the Electronics Goes Green 2016+, Berlin, Germany, 6-9 September 2016; pp. 1-9.

18. Wieser, H.; Tröger, N. Exploring the inner loops of the circular economy: Replacement, repair, and reuse of mobile phones in Austria. J. Clean. Prod. 2018, 172, 3042-3055. [CrossRef]

19. Hernandez, R.J.; Miranda, C.; Goñi, J. Empowering Sustainable Consumption by Giving Back to Consumers the 'Right to Repair'. Sustainability 2020, 12, 850. [CrossRef]

20. Wijkman, A.; Skånberg, K. The Circular Economy and Benefits for Society; Club of Rome: Rome, Italy, 2015.

21. Diez, L.; Marangé, P.; Levrat, É. Maintenance best way for meeting the challenge of regeneration. IFAC-PapersOnLine 2016, 49, 49-54. [CrossRef]

22. Burger, M.; Stavropoulos, S.; Ramkumar, S.; Dufourmont, J.; van Oort, F. The heterogeneous skill-base of circular economy employment. Res. Policy 2019, 48, 248-261. [CrossRef]

23. Temesgen, A.; Storsletten, V.; Jakobsen, O. Circular economy-Reducing symptoms or radical change? Philos. Manag. 2019, 20, 1-20. [CrossRef]

24. Valenzuela, F.; Böhm, S. Against wasted politics: A critique of the circular economy. Ephemer. Theory Politics Organ. 2017, 17, 23-60.

25. Niskanen, J.; Anshelm, J.; McLaren, D. Local conflicts and national consensus: The strange case of circular economy in Sweden. J. Clean. Prod. 2020, 261, 121117. [CrossRef]

26. Spring, M.; Araujo, L. Product biographies in servitization and the circular economy. Ind. Mark. Manag. 2017, 60, 126-137. [CrossRef]

27. Houston, L.; Jackson, S.J.; Rosner, D.K. Values in Repair. In Proceedings of the CHI Conference on Human Factors in Computing Systems (CHI'16), San Jose, CA, USA, 7-12 May 2016.

28. Chapman, J. Emotionally Durable Design: Objects, Experiences and Empathy; Routledge: Oxford, UK, 2015.

29. McLaren, D. In a broken world: Towards an ethics of repair in the Anthropocene. Anthr. Rev. 2018, 5, 136-154. [CrossRef]

30. Graziano, V.; Trogal, K. The politics of collective repair: Examining object-relations in a postwork society. Cult. Stud. 2017, 31, 634-658. [CrossRef]

31. Isenhour, C.; Reno, J. On materiality and meaning: Ethnographic engagements with reuse, repair \& care. Worldw. Waste J. Interdiscip. Stud. 2019, 2, 1.

32. Vinsel, L. Maintenance as Romance: Recuperating Zen and the Art of Motorcycle Maintenance. Continent 2017, 6, 87-91.

33. Baumann, Z. Retrotopia; Polity: Cambridge, UK, 2017.

34. Sennett, R. Together: The Rituals, Pleasures and Politics of Cooperation; Yale University Press: London, UK, 2012.

35. Kvale, S.; Brinkmann, S. Interviews: Learning the Craft of Qualitative Research Interviewing; Sage: Thousand Oaks, CA, USA, 2009.

36. David, M.; Sutton, C.D. Social Research; SAGE Publications: Thousand Oaks, CA, USA, 2011.

37. McManus, M. The Rise of Post-Modern Conservatism: Neoliberalism, Post-Modern Culture, and Reactionary Politics; Springer Nature: Berlin, Germany, 2019.

38. Hawkins, G.; Boarder Giles, D.; Phillips, C.; Zahara, A. Myths of the Circular Economy. Discard Studies,18 November 2019 Available online: https:/ / discardstudies.com/2019/11/18/myths-of-the-circular-economy/ (accessed on 15 February 2021).

39. Ellen MacArthur Foundation. Towards the Circular Economy, Economic and Business Rationale for an Accelerated Transition; Ellen MacArthur Foundation: Cowes, UK, 2013.

40. Kirchherr, J.; Reike, D.; Hekkert, M. Conceptualizing the circular economy: An analysis of 114 definitions. Resour. Conserv. Recycl. 2017, 127, 221-232. [CrossRef]

41. Korhonen, J.; Honkasalo, A.; Seppälä, J. Circular economy: The concept and its limitations. Ecol. Econ. 2018, 143, 37-46. [CrossRef]

42. Illich, I. Tools for Conviviality; Harper \& Row: New York, NY, USA, 1973.

43. Humalisto, N.; Åkerman, M.; Valve, H. Making the circular economy online: A hyperlink analysis of the articulation of nutrient recycling in Finland. Environ. Politics 2020, 1-21. [CrossRef] 
44. European Commission. The European Green Deal; Report No. COM(2019)640 Final December; European Commission: Brussels, Belgium, 2019.

45. European Commission. Europe's Moment: Repair and Prepare for the Next Generation; Report No. COM(2020)456 Final May; European Commission: Brussels, Belgium, 2020. 